\title{
The local cultural sector
}

\section{Reinvigorating its public functions and foundations}

\author{
Anita Kangas
}

\section{Introduction}

In the Nordic tradition, public cultural policy has been endowed with an enlightening and welfarepolitical aim. Nordic cultural policies are based on an overall socio-political objective of furthering the empowerment of the individual, universal enlightenment ("Bildung") and the continued democratisation of society (Nielsen 2003). Locally, an important actor is a municipal cultural sector that is one specialized sector in a municipality's administration. Cultural and art institutions (such as libraries, museums, theatres) are working under the cultural sector administration, although they might sometimes have their own separate administration. According to Gray (2002, pp. 82-83) the arts as a coherent policy sector within local government is weak because of low political salience and a fragmented field of activity, with many actors having a role to play in the provision of services and development of arts policies.

Cultural policy became institutionalized in Finland at the same time as in other Nordic countries, around the 1950s, and during the 1970s and the 1980s the cultural sector was established as one of the sectors in public services with a number of statutory duties. The division of responsibilities between the state and the local government was built up in the same man-

\footnotetext{
Anita Kangas, professor, emerita

University of Jyväskylä,

anita.kangas@jyu.fi
}

ner as other welfare state services: The local government has a crucial role in delivering and providing services, and the state regulates them through legislation including financial support. In the end of the 1980s the ideas of New Public Management hit Finland, and soon after that came the financial recession of the 1990s. Together they changed the position of the cultural sector. (Kangas, 2004)

By the 2010s, Finnish municipalities have been polarizing into strong and weak ones in offering cultural and recreational services. Some of them are struggling with structural changes such as an aging population and migration towards big cities. Due to those changes, they face the diminished possibilities in providing other than main services (such as social and health, education incl. library) and land use. Others have for example a wide variety of cultural services. The contemporary need to reorganize municipal administration and the cultural sector as a service producer is challenged by the ongoing aims to restructure regional and local government in Finland.

As other public sector policies, the cultural policy gets its mandate from the citizens and must therefore in its operations take into account what is best for the citizens. Cultural policies typically observe that culture and art have intrinsic values but they are also recognised instrumentally as striving for goals that are generally beneficial to the citizens. A shift in emphasis towards a greater instrumentalization of the cultural institutions has taken place from the 1990s. The cultural institutions need to demonstrate a clear 
benefit not only for their own sector but also for the sectors and governmental objectives to which they are connecting themselves with.

\section{Aims, data and methodology}

The aim of this article is to analyse the role of the local cultural sectors in Finland and to explore how the sectors are utilizing national cultural policy trends and programs in their development activity. This is obviously cognate with the research where Alasuutari (2016) has illustrated how national cultural policies tend to get synchronized as they tune with international trends. Another approach refers to the concept of isomorphism (DiMaggio \& Powell, $1983)$ describing the process where organisations become more homogeneous and for example copy each other (mimetic), often because of uncertainty. This becomes important especially for organizations that strive for legitimate standing.

First, the earlier research concerning instrumental use of cultural policy is analysed and elaborated upon. This research has commonly analysed the operation and operational emphases of the cultural sectors of municipalities. The focus on these aspects also reveals and brings to the fore the global trends that are applied in nation states.

Second, the empirical research, carried out in 2011, analyses cultural administrators' (directors, secretaries, managers and cultural producers) experiences from their role in the local development activity, their conceptualizations concerning inducements and legitimation for the municipal cultural sector and its impacts.

The empirical data were collected in 2011 using questionnaires (an electronic form), which were emailed to the cultural directors or secretaries of the municipalities. The municipalities $(\mathrm{N}=106)$ were chosen so that they represented different geographical areas: metropolis, big and small cities (altogether 41 ) and rural areas (65). They also included bilingual municipalities and those in which the majority language is Swedish. In 2011, there were 336 municipalities in all of Finland.

Quantitative methods using questionnaires were used to collect data for descriptive and analytical statistical methods including the frequency procedure, cross tabulation and factor analysis. The response rate was $74 \%$.

\section{Instrumental use of culture and art}

Explicitly instrumental forms of cultural policies have aimed at using culture in order to overcome societal challenges, for example in developing neighborhoods or branding cities. Since 2002 this trend has become even more popular. (Belfiore 2002, p. 92)

Based on research and development, four ways can be explored through which this has been done: (1) using the capacity of arts and culture to regenerate local and regional peripheral territories and areas (Bianchini \& Parkinson, 1993; Landry, 2000; Kangas, 2003); (2) using creative arts and heritage to attract investment into cities and regions (linked to competitiveness) (Richards \& Wilson, 2004; Plaza, 2008; Pratt, 2008, Kainulainen, 2005); (3) using the arts to improve social inclusion, social welfare, and social cohesion (Matarasso, 1997; Aspen \& Pløger, 2015; Jeannotte, 2003), and (4) using arts to improve health and to prevent from illnesses (Konlaan, 2001; Staricoff, 2006; Hyyppä, 2013; Livesey \& all, 2012). The applicability of art and culture as tools for development and as solutions to social problems has also triggered critical viewpoints (e.g. Belfiore, 2002; Merli, 2002, Belfiore \& Bennett, 2008).

In those same frames, Skot-Hansen, Hvenegaard Rasmussen and Jochumsen (2013) have analysed the roles of libraries within strategies of culture-led urban regeneration, and found three key orientations: the library as an icon, a placemaker and as community vitalization. Rather than excluding each other, these roles overlap and even contribute to each other. Following fashionable star-architecture designs, libraries are supposed to function as iconic buildings that draw touristic attention and answer to cities' need to increase their attractiveness with the help of architectural wow-effects. However, the library's function as a placemaker requires more of the library interior. More than shelters for books, libraries are supposed to provide a stage for various facilities and experiences, and in this way to extend their physical position from a mere, even if fancy, building to "a transzone between the library and the city" (Skot-Hansen et al., 2013, p. 12). Providing services beyond their traditional objectives of holding books 
and knowledge, libraries are given a significant role in community vitalization by addressing issues of social cohesion and boosting local identity.

The different roles attached to the library coincide with contemporary trends of branding cities and their urban planning, but there appears to run a two-way road between these phenomena. The apparently instrumental use of libraries can also serve to legitimize the library institution, although this can leave open many questions regarding the library's core tasks. This is of interest especially in the welfarepolitical context, where library services are typically organized through municipal cultural sectors.

\section{Empirical analysis: Goals and objectives of the Finnish local cultural sectors}

How do the municipal cultural sectors define their goals? In the survey there were free text questions, and respondents were asked to give information, explanations and their opinions of the objectives of local cultural policy. Based on the answers of cultural administrators many goals could be listed, and their extraction from national and international cultural policy discourses is not self-explanatory.

The goals that were ranked as the most important are the following:

- improve well-being and health of inhabitants

- promote and support local cultural heritage

- improve attractiveness of the municipalities and strengthening their competitiveness among the other municipalities and regions

- increase diverse cultural activities for children and young people

- strengthen communality and community spirit

The most essential goal that the cultural sectors expressed was to add to people's well-being and health. It was also of interest that the role of cultural sector was considered important for developing the image of the municipality. However, there were differences between municipalities' aims. More than others, rural and municipalities of less than 10.000 inhabitants took interest in supporting local cultural heritage. Large and urban municipalities' cultural sectors emphasized more often the objective to strengthen communality. This aim was considered second highest also in small and rural municipalities. The middle- sized, densely populated municipalities underlined more than others the aim to raise children and young people's cultural skills. The objective to increase municipality's attractiveness and competitiveness was popular especially among cultural sectors in municipalities of more than 40.000 inhabitants. Over half of the cultural sectors in municipalities with less than 10.000 people did not consider their role very important for developing art and culture entrepreneurship. However, the importance of the cultural sector as a supporting factor for municipal trade and industry activities was emphasized in the largest municipalities, in which the sectors had also written this objective down as an emphasis of their activities. Indeed, almost $80 \%$ of the respondents in cultural sectors of large municipalities with more than 40.000 inhabitants considered their role at least somewhat important for municipal trade and industry activities. (See more Kangas \& Ruokolainen, 2012)

The documented objectives can be easily connected with the discussions that the Ministry of Education and Culture together with the Ministry of Social Affairs and Health or the Ministry of Employment and Economy have instilled and that have led to a diversity of working groups and recommendations. (Kangas \& Pirnes, 2015) For example The Ministry of Education and Culture can well be described through the objectives that build on its social impact measures, which have been documented in the State budget. In 2011 the objectives emphasized (1) the need to strengthen the basis of culture by supporting people's access to culture and knowledge, media, art and heritage education, by maintaining cultural and environmental heritage and by enhancing the functionality of national, regional and local art and cultural administration and the internationalization of culture (with regard to challenges concerning globalization and technological and sustainable developments); (2) the need to improve the circumstances for creative work by developing the support system for art and culture, by adding diversity to artists' income sources and developing a functional system of copyrights, and by strengthening the prerequisites for cultural and creative entrepreneurship; (3) the need to support all population groups' access to cultural activities by improving the availability and accessibility of cultural services and heritage on local and regional levels and by enhancing the development of cultural diversity; (4) the need to strengthen cultural economy and creative economy by developing and 
expanding the funding basis for cultural activities, by supporting cultural export and by improving the chances to utilize copyrights. (Valtion talousarvioesitys, 2011)

Even if the discourse on strengthening the prerequisites for creativity has been a dominant rhetoric in cultural and social policy documents from the late 1990's to the present (and also in the objectives above), as a goal it did not jump to the front of the list written by municipal cultural administrators. A similar kind of issue appearing strongly in the discourse is endorsing internationalization and multiculturalism. Furthermore, although supporting professional artists and performers is one of the most central goals of the national cultural policy of the Arts Promotion Centre in Finland, it has not domesticated to the local level - this goal only comes up in the answers of sporadic municipalities.

\section{Future strategic planning of the municipal cultu- ral sector}

In the research, the visions of the cultural administrators were studied concerning future prospects and strategic emphases, which they connected with the development of their sector. The respondents were asked how important certain trends and actions are for developing municipal cultural services in the future. By using factor analysis with varimax rotation ${ }^{1}$ altogether six different dimensions were discovered describing the strategic emphases of the municipal cultural sector, and how the position of the sector as producer of public services can be strengthened.

Percentage of variance explained was $60,4 \%$. (See more Kangas \& Ruokolainen, 2012)

These six different functional emphases through which the municipal cultural sector seems to seek a model to develop its functions are presented in the following factors.

1. Building of creative clusters. Variables like 'development of clusters and networks of cultural agents and entrepreneurs', 'growth of the creative sectors in regions', 'urbanisation' and 'strong partnerships between private and third sector in service production' are highly loaded. In addition 'number of adventure and tourism services' and 'technological development', are relevant signifier of this factor..

2. Strong organised cooperation in the production of public cultural services. Highly loaded variables are: 'effective joint use of facilities and human resources', 'increasing the share of municipal services that are subject to a charge', 'developing online services' and 'strengthening the service voucher system'. Also making possible successful 'consolidations of municipalities' serves this purpose.

3. Strong role of state subsidies in municipalities. The starting point is two hopes: firstly, the state would increase the amount of euros in state subsidies targeted to cultural sector in the municipalities, earmarking specifically for art and culture and secondly, the state would include new cultural production and new actorships into the state subsidies. Far from these hopes are the variables concerning privatization and increasing service charges.

4. Marketization of public cultural services. This factor is described by the will to apply and strengthen the following functions in the cultural sector: customer-producer model, internal purchaser-provider model, privatization, and increasing number of managers.

5. Developing operations through project management. The dimension emphasizes the strong role of joint research and joint development projects in regional development activities. It is related to the positive charge of the consolidation of municipalities.

6. Applying service design in developing cultural productions. The respondents believed that new courses of action could be found by implementing service design, developing brands for municipal cultural services, re-packaging public services and developing different new service concepts.

The differences in strategic focus between different types of municipalities were examined through the factor scores. The result confirmed the assumption concerning the polarization of municipalities' cultural policies. Marketization of services, service design, creative urban clusters and organized cooperation in the service production of the municipality were characteristic for the operation of urban municipalities more than for other municipalities. The significance of state subsidies became emphasized in rural municipalities and urban municipalities had clearly different views on the matter. One interesting issue was 
project management, that did not divide the different types of municipalities a lot. Interestingly, project management was not significant for the operation of the biggest cities of the regions.

\section{Conclusion}

The Finnish cultural policy model is characterized by strong actors on the local level. According to the welfare oriented cultural policy, the state provides financial support for municipalities and local institutions. In the municipalities cultural services are of- fered as part of the public services. The main goal of the local cultural policy is the principle of equality. Through this local cultural policy is connected with democratization of culture and cultural democracy.

In this article, it is analysed how local cultural policy sectors define their roles, goals and impacts and how they utilize national policy trends and fashion in their development environments. According to the results it seems that the cultural sectors' practitioners are informed about the national cultural policy goals and trends, and research findings. These become embed-

Pattern Matrix ${ }^{\mathrm{a}}$

\begin{tabular}{|c|c|c|c|c|c|c|}
\hline & \multicolumn{6}{|c|}{ Factor } \\
\hline & 1 & 2 & 3 & 4 & 5 & 6 \\
\hline Clusters and networks of cultural agents and entrepreneurs &, 726 & & & & & \\
\hline Urbanisation & 623 & & & & & \\
\hline Growth of the creative sectors &, 571 & & & & & \\
\hline $\begin{array}{l}\text { Strong partnerships between private and third sector in culturalservice } \\
\text { production }\end{array}$ & ,536 & & & & & \\
\hline Adventure and tourism services & ,438 & & & & & \\
\hline Technological development & ,354 & & & & & \\
\hline Effective joint use of human resources & & ,674 & & & & \\
\hline Effective of facilities & &, 641 & & & & \\
\hline Service charge & &, 546 &,- 325 & & & \\
\hline Developing online services & & ,421 & & & & \\
\hline Service voucher system for cultural sector & &, 363 & & & & \\
\hline Consolidation of municipalities & & ,326 & & & & \\
\hline Increase state subsidy for cultural sector & & & ,969 & & & \\
\hline Earmarking state subsidies for cultural sector & & & ,449 & & ,359 & \\
\hline New cultural production and new actors into the state subsidies & & & ,375 & & & \\
\hline Purchaser-provider model (internal) & & & &, 778 & & \\
\hline Purchaser-provider model (external) & & & &, 691 & & \\
\hline Privatisation & & & & ,638 & & \\
\hline Increasing number of managers and producers & & & & ,337 & & \\
\hline Increasing number of regional developers & & & & &, 888 & \\
\hline Increase of project activities (R \& D) & & & & & ,680 & \\
\hline Service design & & & & & &, 845 \\
\hline Branding & & & & & &, 572 \\
\hline Re-packaging public services and new service concepts & & & & & & ,479 \\
\hline
\end{tabular}

Extraction Method: Principal Axis Factoring.

Rotation Method: Promax with Kaiser Normalization.

a. Rotation converged in 14 iterations.

Table 1. Rotated factor matrix: Operational environments for the future cultural planning. 
ded in the sectors' functions. Their future strategies show that many goals written by national cultural policy actors are truly adopted on the local level. To what extent they can actually be reached and whether there is room for reinvigorating cultural sectors' public functions and foundations depends on the municipalities. For example, the administrators of the cultural sector define their main aim to increase the well-being of in habitants and the sense of community. This is a good example to show that the cultural sector is a possible tool for policy development in other policy sectors and it can be utilized within these other contexts. Along with the more instrumental uses of culture, the autonomic role of arts and culture and their intrinsic value are mentioned, emphasised especially with heed to the position of artists and the need to increase state subsidies accordingly.

The empirical analysis shows that the cultural political objectives beneficial to other policy sectors are well recognised at the local level and in part well domesticated, too. According to municipal cultural sectors' resources, the recommendations of ministries' joint initiatives for cultural political guidelines with instrumental applications of art and culture are registered - at least in the rhetorical level of municipalities' branding strategies with high cultural profiles (Alasuutari, 2016). Indeed, the instrumental use of cultural services can offer a means of legitimation for institutions such as libraries and museums as "modern" and "up-to-date" and "keeping up with the development". But again, this is also illustrative of policy synchronization. As Alasuutari (2016) maintains, in outlining strategies and making policy decisions organisations intend to be rational actors, but the acting as rational civil servants and politicians is also dependent on the international fashionable ideas and policy trends.

Although the arm's length principle continues to work as the cultural political norm strengthening the role of local cultural sectors among other bodies distinct from central governance, art and culture are increasingly attached with other policy concerns (Gray, 2002). As described by Gray (2002, pp. 8081), development of arts at the level of local government has largely been based on this kind of attachment, which has also set the frame for assessing the achievement of arts policy objectives. The example of the changing and new roles of the library is nevertheless illustrative of how cultural institutions seek to find relegitimation to their activities by making use of this attachment or instrumentalization. However, as has been repeatedly pointed out, this can eventually be harmful for maintaining cultural policy for culture per se and weaken the sector's position within municipal administration.

\section{Acknowledgements}

I am grateful for comments from PhD Eliza Kraatari, which enabled many improvements to this paper.

\section{Note}

1. The start of factor analysis is a correlation matrix, in which the intercorrelations between the studied variables are presented. The dimensionality of this matrix can be reduced by "looking for variables that correlate highly with a group of other variables, but correlate very badly with variables outside of that group" (Field, 2000, p. 424). These variables with high intercorrelations could well measure one underlying variable, which is called a 'factor.' After a varimax rotation (Kaiser 1958) each original variable tends to be associated with one (or a small number) of factors, and each factor represents only a small number of variables.

\section{References}

Aspen, J \& Pløger, J (2015). Den Vitale Byen. Oslo: Spartacus.

Alasuutari, P (2016). The synchronization of national policies: ethnography of the global tribe of moderns. London: Routledge, Taylor \& Francis Group.

Belfiore, E (2002). Art as a means of alleviating social exclusion: Does it really work? A critique of instrumental cultural policies and social impact studies in the UK. International Journal of Cultural Policy, Vol 8, no 1, pp. 91-106.

Belfiore, E \& Bennett, O (2008). The social impact of the arts: An intellectual history. Basingstoke : Palgrave Macmillan.

Bianchini, F \& Parkinson, M (1993). Cultural Policy and Urban Regeneration: The West European Experience. Manchester University Press. 
DiMaggio, PJ \& Powell, WW (1983). The Iron Cage Revisited: Institutional Isomorphism and Collective Rationality in Organizational Fields. American Sociological Review, Vol. 48, no. 2, p. 147-160.

Field, A (2000). Discovering Statistics using SPSS for Windows. London - Thousand Oaks - New Delhi: Sage.

Gray, C (2002). Local government and the arts. Local Government Studies, Vol 28, no. 1, pp. 77-90.

Hyyppä, M (2013). Kulttuuri pidentää ikää. PerSona. Helsinki: Duodecim

Jeannotte, S (2003). Singing alone? The contribution of cultural capital to social cohesion and sustainable communities. International Journal of Cultural Policy, Vol 9, no. 1 pp. 35-49.

Kainulainen, K (2005). Kunta ja kulttuurin talous: tulkintoja kulttuuripääoman ja festivaalien aluetaloudellisista merkityksistä. Tampere: Tampereen Yliopistopaino Oy - Juvenes Print.

Kaiser, HF (1958). The varimax criterion for analytic rotation in factor analysis. Psychometrica, Vol 23, no. 3, pp 187-200.

Kangas, A (2004). New Clothes for Cultural Policy. Ahponen, Pirkkoliisa \& Kangas, Anita (eds). Construction of cultural policy. Jyväskylä: Minerva, pp. 21-41.

Kangas, A \& Ruokolainen, V (2012). Toimintamalli muutoksessa. Tutkimus kuntien kulttuuripalveluista. Helsinki: Cupore publication 16.

Kangas, A \& Pirnes, E (2015). Kulttuuripoliittinen päätöksenteko, lainsäädäntö, hallinto ja rahoitus. In I. Heiskanen, A. Kangas, \& R. Mitchell (Eds.), Taiteen ja kulttuurin kentät. (pp. 23-108). Tietosanoma Oy.

Konlaan, BB (2001). Cultural experience and health: The coherence of health and leisure time activities. Umeå: Umeå University.

Landry, C (2000). The creative city: A toolkit for urban innovators. London: Earthscan.

Livesey, L, Morrison, I, Clift, S \& Camic, P (2012). Benefits of choral singing for social and mental wellbeing: qualitative findings from a cross-national survey of choir members, Journal of Public Mental Health, Vol. 11 Iss: 1, pp.10 - 26.

Kay, A (2000). Art and community development: the role the arts have in regenerating communities Community Development Journal Vol 35, no 4: 414424.

Matarasso, F (1997). Use or Ornament?: the Social Impact of Participation in the Arts. Bournes Green: Comedia.

Merli, P (2002). Evaluating the social impact of participation in arts activities. A critical review of Francois Matarasso's "Use or Ornament?". International Journal of Cultural Policy, Vol 8, no.1, pp. 107-118.

Nielsen, HK (2003). Cultural policy and evaluation of quality. International Journal of Cultural Policy, Vol 9, no 3, pp. 237-245.

Richards, G \& Wilson, J (2004). The Impact of Cultural Events on City Image: Rotterdam, Cultural Capital of Europe 2001. Urban Studies, Vol. 41 no. 10, pp. 1931-1951.

Plaza, B (2008). On Some Challenges and Conditions for the Guggenheim Museum Bilbao to be an Effective Economic Re-activator. International Journal of Urban and Regional Research, Vol 32 no 2, pp. 506-517.

Pratt, AC (2008). Creative cities: the cultural industries and the creative class, Geografiska Annaler: Series B, Human Geography Vol 90, no 2, pp. 107-117.

Skot-Hansen, D, Hvenegaard Rasmussen, C \& Jochumsen, H (2013). The role of public libraries in culture-led urban regeneration, New Library World, Vol. 114 no 1/2, pp. 7 - 19.

Staricoff, RL (2006). Arts is health: the value of evaluation. Journal of the Royal Society for the Promotion of Health. Vol 126, no 3, pp. 116-120.

Valtion talousarvioesitys 2011. http://budjetti. vm.fi/indox/sisalto.jsp?year=2011\&lang=fi\&mai ndoc $=/ 2011 / \mathrm{aky} / \mathrm{aky} \cdot \mathrm{xml} \& \& \mathrm{id}=/ 2011 / \mathrm{aky} / \mathrm{pl} 29 /$ pl29ml80_1.html, 26.8.2016 